\title{
PERBANDINGAN HASIL ANALISIS DUA LABORATORIUM MENGGUNAKAN METODE YANG BERBEDA
}

\section{COMPARISON OF THE ANALYSIS RESULT BETWEEN TWO LABORATORIES USING DIFFERENT METHODS}

\author{
Sri Murniasih*, Agus Taftazani \\ Pusat Sains dan Teknologi Akselerator - Badan Tenaga Nuklir Nasional \\ Jl. Babarsari Kotak Pos 6601 ykbb, Yogyakarta 55010 \\ *smurni83@gmail.com
}

Diterima 8 Nopember 2016, diterima dalam bentuk perbaikan 13 Maret 2017, disetujui 11 April 2017

\begin{abstract}
ABSTRAK
PERBANDINGAN HASIL ANALISIS DUA LABORATORIUM MENGGUNAKAN METODE YANG BERBEDA. Telah dilakukan perbandingan hasil analisis suatu sampel abu vulkanik pada dua laboratorium dengan metode analisis yang berbeda. Pekerjaan ini bertujuan untuk meningkatkan mutu suatu laboratorium pengujian serta menjalin kerjasama dengan laboratorium pengujian dari Negara lain. Sampel diuji di laboratorium AAN - Pusat Sains dan Teknologi Akselerator (PSTA) menggunakan metode AAN, sedangkan pada Universitas Texas (UT) USA menggunakan ICP-MS dan ENAA. Dari target 12 unsur, laboratorium AAN - PSTA mampu menyajikan data analisis 11 unsur. Hasil perbandingan diketahui bahwa analisis unsur $K$, $\mathrm{Mn}$, Ti dan Fe dari kedua laboratorium mempunyai perbandingan yang sangat baik dan saling berdekatan.Hal ini diketahui dari nilai RSD dan koefisien korelasi hasil analisis kedua laboratorium. Sedangkan dilihat dari perbedaan hasil diketahui bahwa hasil analisis unsur Al, Na, K, Fe, V, Mn, Ti, Cr dan As dari kedua laboratorium tidak beda signifikan. Dari 11 unsur yang dilaporkan, hanya unsur Zn yang mempunyai nilai berbeda signifikan untuk dua laboratorium.
\end{abstract}

Kata kunci: metode analisis, AAN, AANE, ICP-MS, uji banding

\section{ABSTRACT}

COMPARISON OF THE ANALYSIS RESULT BETWEEN TWO LABORATORIES USING DIFFERENT METHODS. Comparison of the analysis result of volcano ash sample between two laboratories using different analysis methods. The research aims to improve the testing laboratory quality and cooperate with the testing laboratory from other country. Samples were tested at the Center for Accelerator of Science and Technology (CAST)-NAA laboratory using NAA, while at the University of Texas (UT) USA using ICP-MS and ENAA method. From 12 elements of target, CAST-NAA able to present 11 elements of data analysis. The comparison results shows that the analysis of the $\mathrm{K}, \mathrm{Mn}, \mathrm{Ti}$ and Fe elements from both laboratories have a very good comparison and close one to other. It is known from RSD values and correlation coefficients of the both laboratories analysis results. While observed of the results difference known that the analysis results of $\mathrm{Al}, \mathrm{Na}, \mathrm{K}, \mathrm{Fe}, \mathrm{V}, \mathrm{Mn}, \mathrm{Ti}, \mathrm{Cr}$ and As elements from both laboratories is not significantly different. From 11 elements were reported, only $\mathrm{Zn}$ which have significantly different values for both laboratories.

Keywords: analysis method, NAA, ENAA, ICP-MS, comparison testing.

\section{PENDAHULUAN}

Untuk mengetahui kandungan suatu sampel selalu dilakukan analisis. Analisis dapat dilakukan dengan uji rusak maupun tak rusak. Salah satu metode uji tak rusak adalah metode Analisis Aktivasi Neutron (AAN) Metode ini mampu menentukan berbagai unsur baik mayor, minor maupun kelumit secara serempak dengan mengandalkan energi gamma karakteristik yang dipancarkan oleh setiap isotop. Tidak semua laboratorium mampu menerapkan metode AAN karena metode ini memerlukan suatu reaktor sebagai sumber neutron untuk mengaktivasi sampel yang akan dianalisis. Metode AAN merupakan suatu metode analisis tidak baku sehingga hasil analisis yang diperoleh harus selalu disertai dengan validasinya. Keakuratan suatu hasil analisis AAN dapat pula dilakukan dengan melakukan perbandingan hasil analisis suatu laboratorium AAN yang satu dengan laboratorium AAN lainnya [1]. 
Metode AAN mempunyai beberapa keunggulan antara lain preparasi sampel yang tidak memerlukan perlakukan awal (pre-treatment) seperti digestion yang menyebabkan kemungkinan kehilangan beberapa unsur volatil dapat dihindari [2]. Selain itu, batas limit deteksi pengukuran bisa mencapai orde ppb untuk beberapa unsur tertentu tergantung daya reaktor dan cross section atom [3]. Laboratorium AAN - PSTA bekerjasama dengan laboratorium AAN - UT, USA untuk melakukan interkomparasi analisis kandungan unsur pada sampel abu vulkanik gunung Merapi. Kegiatan ini bertujuan untuk mengetahui kandungan unsur mayor, minor dan kelumit secara akurat serta sebagai media dalam peningkatan kompetensi laboratorium.

Pada penelitian ini, akan disajikan hasil interkomparasi dari dua laboratorium yaitu lab. AAN - PSTA, Indonesia menggunakan metode AAN dengan lab. AAN - UT, USA menggunakan metode epithermal neutron activation analysis (ENAA) dan inductively coupled plasma mass spectrometry (ICP-MS). Sampel yang diuji adalah abu vulkanik hasil erupsi gunung Merapi 2010. Analisis kandungan unsur mayor, minor dan trace merupakan target dalam penelitian ini. Kegiatan ini merupakan kegiatan bersama dalam rangka membangun kerjasama dengan international atomic energy agency (IAEA) dalam hal peningkatan metode analisis nuklir dan pemanfaatan nuklir untuk tujuan damai.

\section{METODOLOGI}

\section{Alat dan Bahan}

Laboratorium AAN - PSTA di Indonesia menggunakan sumber radiasi reaktor Kartini dengan daya 100 $\mathrm{kW}$, spektrometer gamma dilengkapi dengan detektor HPGe GEM35P4-83, MCA 8K dan Pb shielding yang digunakan sebagai sistem pengukuran sampel pasca iradiasi, timbangan semi mikro guna menimbang sampel yang akan digunakan seberat $100 \mathrm{mg}$. Sedangkan di laboratorium AAN - UT, USA menggunakan sumber radiasi reaktor TRIGA dengan daya 1,1 MW, spektrometer gamma yang dilengkapi dengan detektor HPGe serta timbangan semi mikro guna menimbang sampel yang akan digunakan seberat $300 \mathrm{mg}$.

Sampel yang digunakan dalam penelitian ini berupa abu vulkanik yang diambil dari erupsi gunung Merapi tahun 2010 pada radius $15-20 \mathrm{Km}$. Sampel abu vulkanik berwarna abu-abu dengan diameter $<0.074$ $\mathrm{mm}$. Sampel dilakukan uji homogenisasi menggunakan alat homogenisasi. Sampel dimasukkan dalam botol polietilen sebanyak $100 \mathrm{mg}$. Kedua laboratorium menggunakan NIST 1633b sebagai kontrol dalam analisis unsur. Pada laboratorium AAN - PSTA digunakan larutan stock dari E-Merck untuk analisis kuantitatif.

\section{Preparasi Sampel}

Sampel abu vulkanik dan SRM NIST 1633b (sebagai kontrol) ditimbang menggunakan timbangan semi mikro seberat $100 \mathrm{mg}$ kemudian dimasukkan dalam vial polietilen selanjutnya dibungkus dengan plastik klip dan diberi kode sebagai identifikasi. Vial yang telah berisi sampel, standar, SRM dan vial kosong (sebagai blanko) dimasukkan dalam kelongsong C-20 dan siap diiradiasi menggunakan reaktor Kartini pada daya 100 kW.

\section{Pembuatan larutan standar}

Tabel 1. Kandungan standar campuran yang digunakan untuk analisis kuantitatif.

\begin{tabular}{lcc}
\hline Unsur & Vol. yang diambil $(\mathrm{mL})$ & Konsentrasi $(\mu \mathrm{g})$ \\
\hline $\mathrm{Al}$ & 1,00 & 1000 \\
$\mathrm{Fe}$ & 1,00 & 1000 \\
$\mathrm{Na}$ & 0,05 & 50 \\
$\mathrm{~K}$ & 0,50 & 500 \\
$\mathrm{~V}$ & 0,01 & 10 \\
$\mathrm{Ti}$ & 0,10 & 100 \\
$\mathrm{Si}$ & 1,00 & 1000 \\
$\mathrm{Mn}$ & 0,01 & 10 \\
$\mathrm{Mg}$ & 0,10 & 100 \\
$\mathrm{As}$ & 0,01 & 10 \\
$\mathrm{Cr}$ & 0,01 & 10 \\
$\mathrm{Zn}$ & 0,01 & 10 \\
\hline
\end{tabular}


Pada penelitian yang dilakukan di laboratorium AAN - PSTA digunakan lautan standar campuran guna menentukan konsentrasi kandungan unsur dalam sampel (analisis kuantitatif). Larutan standar campuran dibuat dengan mengambil beberapa $\mathrm{mL}$ tertentu dari masing - masing larutan stock tiap-tiap unsur dengan kadar 1000 $\mu \mathrm{g} / \mathrm{mL}$ sehingga diperoleh kandungan larutan standar campuran seperti pada Tabel 1.

\section{Iradiasi dan Pengukuran Sampel}

Iradiasi dilakukan menggunakan fasilitas Pneumatic System di reaktor Kartini pada daya $100 \mathrm{~kW}$ dengan fluks neutron berkisar $2 \times 10^{11} \mathrm{n} . \mathrm{cm}^{-1} . \mathrm{s}^{-1}$ selama 5 menit untuk unsur Al, Ti, Mn, Mg V dan Si. Unsur K, Na dan As diiradiasi 6 jam sedangkan unsur $\mathrm{Fe}, \mathrm{Cr}$ dan Zn diiradiasi $2 \times 6$ jam. Sampel, standar dan blanko diiradiasi pada waktu yang sama kemudian didinginkan selama 5 menit dan dicacah selama 300 detik untuk unsur $\mathrm{Al}, \mathrm{Ti}, \mathrm{Mn}, \mathrm{Mg}$ $\mathrm{V}$ dan Si. Unsur K, Na, As didinginkan selama 2-3 hari dan dicacah selama 1000 detik sedangkan unsur $\mathrm{Fe}, \mathrm{Cr}$, Zn didinginkan 10-15 hari dan dicacah selama 5000 detik. Pengukuran sampel menggunakan spektrometer gamma dengan detektor HPGe yang dilengkapi software Genie 2000.

\section{Analisis Kualitatif dan Kuantitatif}

Analisis kualitatif dalam metode AAN dilakukan berdasarkan energi karakteristik yang dipancarkan oleh setiap unsur metastabil setelah diaktivasi oleh neutron. Energi karakteristik tiap unsur berbeda-beda dengan kelimpahan tertentu. Pada umumnya unsur mempunyai 1-5 energi karakteristik dengan kelimpahan yang relatif besar. Untuk memastikan kandungan unsur dalam sampel perlu dilihat juga energi karakteristik lainnya jika unsur tersebut mempunyai lebih dari 1 energi karakteristik.

Analisis kuantitatif dilakukan dengan membandingkan net area spektrum tiap unsur dalam sampel dengan net area spektrum dari standar yang telah diketahui konsentrasinya. Perhitungan dilakukan dengan mengembalikan aktivitas tiap unsur ke waktu awal pasca iradiasi $\left(t_{0}\right)$. Saat sampel diradiasi dengan waktu tertentu $\left(t_{\mathrm{i}}\right)$, kemudian didinginkan pada waktu yang ditentukan $\left(t_{\mathrm{d}}\right)$ selanjutnya sampel diukur dengan waktu $\left(t_{\mathrm{c}}\right)$ sehingga konsentrasi unsur dapat dihitung dengan persamaan (1) dan (2).

$$
\begin{aligned}
& C=A\left(m \cdot k \cdot \phi \cdot e^{-\lambda t_{d}}\left(1-e^{-\lambda t_{c}}\right)\left(1-e^{-\lambda t_{i}}\right)\right)^{-1} \\
& \text { dengan } \\
& k=\frac{\alpha \sigma \varepsilon \gamma N_{A}}{M \lambda}
\end{aligned}
$$

Dimana $C$ adalah konsentrasi unsur dalam sampel $(\mathrm{g} / \mathrm{g}), A$ adalah net area, $m$ adalah berat sampel $(\mathrm{g}), \boldsymbol{\phi}$ adalah fluks neutron $\left(\mathrm{cm}^{-2} \mathrm{~s}^{-1}\right), \sigma$ adalah cross section absorpsi selektif $\left(\mathrm{cm}^{2}\right), \alpha$ adalah kelimpahan isotop dari unsur, $\varepsilon$ adalah efisiensi detector, $\gamma$ adalah rasio energi foton dari unsur $N_{A}$ adalah bilangan avogadro $=6,023 \times 10^{23}$ atoms $\mathrm{g}^{-1}$ atom $^{-1}, M$ adalah berat nuklida dari unsur $(\mathrm{amu}), k$ adalah konstanta peluruhan $\left(\mathrm{s}^{-1}\right)$ [3]. Penggunaan SRM dalam penelitian ini dimaksudkan sebagai kontrol hasil analisis kuantitatif yang dilakukan. Apabila nilai SRM yang diperoleh dari pengukuran SRM jauh dari nilai sertifikat maka hasil analisis sampel dianggap tidak valid sedangkan jika hasil pengukuran SRM mendekati nilai sertifikat maka hasil analisis sampel dikatakan valid.

\section{HASIL DAN PEMBAHASAN}

Pada preparasi, sebelum sampel dibagikan ke laboratorium-laboratorium untuk dianalisis maka perlu dilakukan uji homogenisasi sampel. Uji homogenitas dan stabilitas sampel dilakukan dengan mengukur sampel sebanyak 3 kali menggunakan spektrometer XRF. Sampel diambil secara acak sebanyak 10 titik pada sampel yang telah lolos 200 mesh dan telah dihomogenkan menggunakan alat homogenisasi. Pada uji homogenisasi sampel sebagai parameter uji digunakan unsur $\mathrm{Sr}$ dan $\mathrm{Ba}$ di mana hasil analisis sampel akan dilakukan uji statistik yaitu uji F. Hasil uji homogenitas sampel menggunakan spektrometer XRF disajikan pada Tabel 2, sedangkan hasil analisis statistik uji F disajikan pada Tabel 3.

Hasil uji statistik diketahui $F_{\text {hitung }}<F_{\text {tabel }}$ dimana $1,504<3,179$, hal ini menunjukkan bahwa sampel tidak beda signifikan sekalipun diambil dari titik berbeda dalam satu wadah sampel. Sehingga sampel sudah dapat dikatakan telah homogen dan siap digunakan untuk program interkomparasi laboratorium [14,15]. 
Tabel 2. Hasil uji homogenitas sampel dengan parameter unsur Ba dan $\mathrm{Sr}$ menggunakan spektrometer XRF.

\begin{tabular}{ccccccccc}
\hline \multirow{2}{*}{ Sampel } & \multicolumn{9}{c}{ Ba } & \multicolumn{5}{c}{ Sr } \\
\cline { 2 - 9 } & 1 & 2 & 3 & rerata & 1 & 2 & 3 & rerata \\
\hline 1 & 643,699 & 641,123 & 645,923 & 643,582 & 546,564 & 544,097 & 541,975 & 544,212 \\
2 & 652,192 & 654,236 & 656,984 & 654,471 & 501,459 & 502,712 & 507,045 & 503,739 \\
3 & 623,542 & 631,875 & 626,972 & 627,463 & 523,870 & 511,904 & 519,984 & 518,586 \\
4 & 650,678 & 654,421 & 651,077 & 652,059 & 533,973 & 528,875 & 530,751 & 531,200 \\
5 & 600,876 & 609,663 & 607,981 & 606,173 & 528,057 & 522,887 & 529,091 & 526,678 \\
6 & 649,491 & 645,312 & 643,297 & 646,033 & 532,004 & 530,812 & 535,421 & 532,746 \\
7 & 666,877 & 658,342 & 653,87 & 659,696 & 510,905 & 514,544 & 511,078 & 512,176 \\
8 & 609,988 & 623,219 & 610,512 & 614,573 & 528,997 & 526,096 & 528,911 & 528,001 \\
9 & 663,687 & 660,578 & 661,096 & 661,787 & 558,465 & 556,006 & 559,043 & 557,838 \\
10 & 635,912 & 640,902 & 638,643 & 638,486 & 522,224 & 525,750 & 521,866 & 523,280 \\
\hline
\end{tabular}

Tabel 3. Hasil statistik uji F untuk mengetahui homogenitas sampel.

\begin{tabular}{lcc}
\hline & Variable 1 & Variable 2 \\
\hline Mean & 640,432 & 527,845 \\
Variance & 357,226 & 237,481 \\
Observations & 10,000 & 10,000 \\
$d f$ & 9,000 & 9,000 \\
$F$ & 1,504 & \\
$P(F<=f)$ one-tail & 0,276 & \\
$F$ Critical one-tail & 3,179 & \\
\hline
\end{tabular}

Pada laboratorium AAN - PSTA, analisis sampel dilakukan menggunakan metode AAN relatif, sedangkan pada laboratorium AAN UT analisis sampel dilakukan menggunakan dua metode yang berbeda yaitu ICP-MS dan AAN epithermal. Dari hasil analisis, laboratorium AAN - PSTA mampu menyajikan data analisis 11 dari 12 unsur yang diminta, begitu pula dengan laboratorium AAN - UT. Hasil analisis yang disampaikan oleh UT merupakan rerata dari tiga metode yang digunakan, sedangkan data yang disajikan oleh laboratorium AAN PSTA merupakan rerata dari 5 kali pengulangan analisis menggunakan metode AAN.

Analisis kualitatif dilakukan berdasarkan isotope masing-masing untuk unsur Al dilakukan dengan isotope ${ }^{28} \mathrm{Al}$ pada tenaga $1779 \mathrm{keV}$, unsur Mg dilakukan dengan isotope ${ }^{27} \mathrm{Mg}$ pada tenaga $1014 \mathrm{keV}$, unsur $\mathrm{Mn}$ dilakukan dengan isotope ${ }^{56} \mathrm{Mn}$ pada tenaga $1810,7 \mathrm{keV}$, unsur Ti dilakukan dengan isotope ${ }^{51} \mathrm{Ti}$ pada tenag $320,1 \mathrm{keV}$, unsur $\mathrm{V}$ dilakukan dengan isotope ${ }^{52 \mathrm{~V}}$ pada tenaga $1434,1 \mathrm{keV}$, unsur As dilakukan dengan isotope ${ }^{76} \mathrm{As}$ pada tenaga $559,1 \mathrm{keV}$, unsur $\mathrm{Na}$ dilakukan dengan isotope ${ }^{24} \mathrm{Na}$ pada tenaga $1368,6 \mathrm{keV}$, unsur $\mathrm{K}$ dilakukan dengan isotope ${ }^{42} \mathrm{~K}$ pada tenaga $1524,6 \mathrm{keV}$, unsur $\mathrm{Cr}$ dilakukan dengan isotope ${ }^{51} \mathrm{Cr}$ pada tenaga $320,1 \mathrm{keV}$, unsur Fe dilakukan dengan isotope ${ }^{59} \mathrm{Fe}$ pada tenaga 1099,2 keV, unsur Zn dilakukan dengan isotope ${ }^{65} \mathrm{Zn}$ pada tenaga $1115,6 \mathrm{keV}$.

Untuk memastikan kebenaran dari hasil analisis kuantitatif sampel maka dilakukan uji validasi metode. Uji validasi dilakukan dengan menggunakan SRM NIST 1633b Constituent Elements in Coal Fly Ash. Hasil validasi 12 unsur target hanya 11 unsur yang mampunyai hasil validasi memuaskan. Hasil analisis SRM NIST 1633b dibandingkan dengan nilai sertifikat untuk unsur Al, Zn, Ti, Mn, V, Mg, As, K, Na, Fe dan Cr mempunyai standar deviasi $<10 \%$. Pada Gambar 1 dapat diketahui bahwa unsur $\mathrm{Cr}$ mempunyai standar deviasi paling kecil yaitu $0,975 \%$ hal ini disebabkan unsur $\mathrm{Cr}$ sangat sensitif terhadap neutron, selain itu puncak energi gamma 
tunggal unsur $\mathrm{Cr}(320 \mathrm{keV}$ ) yang tidak terinterferensi puncak energi gamma lainnya membuat analisis kuantitatif mudah dilakukan dengan hasil yang memuaskan. Standar deviasi dengan nilai terbesar terdapat pada unsur $\mathrm{Zn}$ yaitu $7,956 \%$. Pada analisis unsur $\mathrm{Zn}$ menggunakan neutron thermal kendala terbesar jika dalam sampel tersebut terdapat unsur Sc yang cukup tinggi sehingga mengganggu puncak unsur Zn. Unsur Sc merupakan unsur yang sangat sensitif terhadap neutron thermal karena cross section yang cukup besar 26,5 barn sedangkan cross section unsur Zn hanya 1,1 barn [13]. Unsur Si yang merupakan salah satu unsur target yang tidak dapat dilaporkan pada penelitian ini mempunyai cross section yang kecil yaitu 0,16 barn sehingga analisis menggunakan neutron thermal kurang sensitif untuk dilakukan. Kandungan Si pada SRM NIST 1633b adalah $23,02 \%$ akan tetapi hasil pengukuran menggunakan spektrometer gamma kurang memberikan puncak spektrum yang sangat kecil sehingga tidak mampu dilakukan analisis kuantitatif.

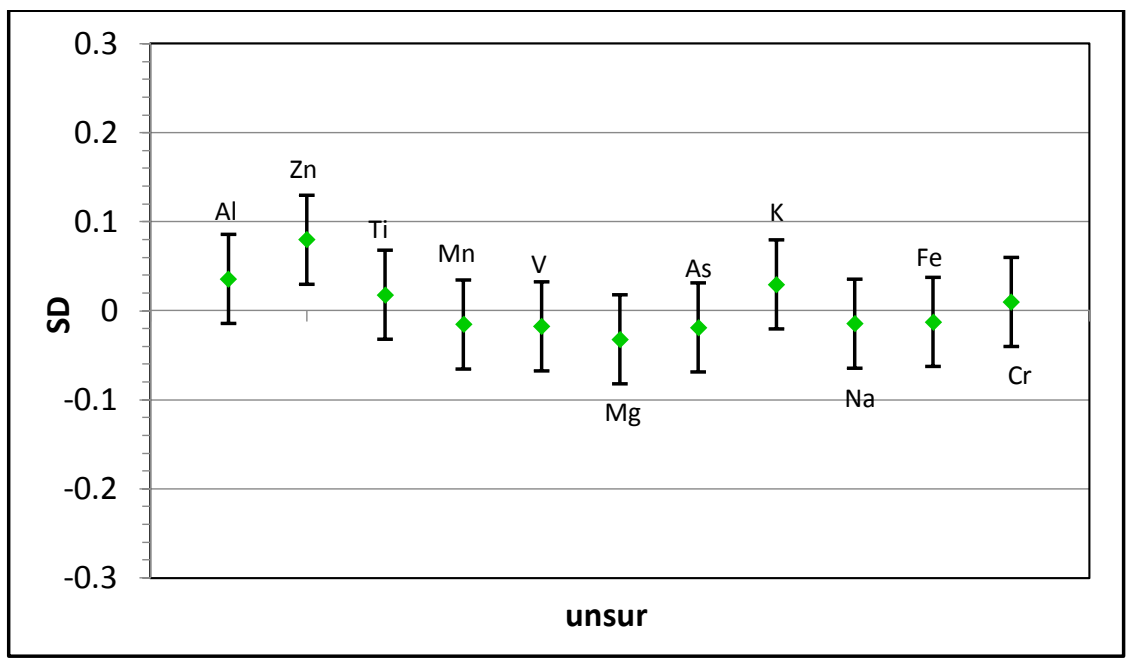

Gambar 1. Hasil validasi metode AAN menggunakan SRM NIST 1633b Constituent Elements in Coal Fly Ash.

Hasil analisis kuantitatif sampel abu vulkanik yang dilakukan oleh laboratorium AAN-PSTA diketahui bahwa terdapat kandungan unsur mayor, minor dan kelumit. Unsur mayor yang terdeteksi antara lain Al dengan konsentrasi 10,104 $\pm 0,742 \%$, Fe dengan konsentrasi 4,919 $\pm 0,082 \%$, Na dengan konsentrasi 2,445 $\pm 0,157 \%$ dan $\mathrm{K}$ dengan konsentrasi $1,658 \pm 0,079 \%$. Unsur minor yang terdeteksi pada sampel meliputi $\mathrm{V}$ dengan konsentrasi 209,839 $\pm 6,955 \mu \mathrm{g} / \mathrm{g}$, Ti dengan konsentrasi 0,426 \pm 0,043\%, Mn dengan konsentrasi 1379,735 \pm $61,022 \mu \mathrm{g} / \mathrm{g}$, Mg dengan konsentrasi $0,469 \pm 0,041 \%$ dan $\mathrm{Zn}$ dengan konsentrasi $0,469 \pm 0,041 \%$. Unsur kelumit yang terdeteksi pada sampel meliputi As dengan konsentrasi 3,382 $\pm 0,197 \mu \mathrm{g} / \mathrm{g}$ dan $\mathrm{Cr}$ dengan konsentrasi 6,211 $\pm 0,612 \mu \mathrm{g} / \mathrm{g}$.

Dari hasil analisis yang disajikan pada Tabel 4 dapat diketahui bahwa konsentrasi rerata dari unsur yang sama dan ditentukan oleh dua laboratorium mempunyai nilai yang berdekatan jika mempunyai nilai SD dan rasio $\mathrm{SD}<2,65$ dengan tingkat kepercayaan 95\% [6,12] seperti pada unsur Al, Na, K, Fe, V, Mn, Ti, Cr dan As. Sedangkan unsur dengan nilai SD dan rasio > 2,65 SD meliputi unsur $\mathrm{Zn}$ dengan nilai analisis beda signifikan dari dua laboratorium. Unsur $\mathrm{Mg}$ dan $\mathrm{Si}$ tidak dapat dianalisis karena hanya salah satu laboratorium yang melaporkannya sehingga tidak dapat dibandingkan. Penentuan Si pada laboratorium AAN-PSTA tidak dapat dilakukan karena Si mempunyai cross section yang rendah sehingga kebolehjadian terjadinya tumbukan dengan neutron thermal sangat sedikit $[7,8]$. Sehingga analisis Si sangat cocok dilakukan menggunakan metode epithermal seperti yang dilakukan pada laboratorium AAN-UT. 
Tabel 4. Hasil analisis sampel abu vulkanik dari 2 laboratorium AAN.

\begin{tabular}{|c|c|c|c|c|c|c|}
\hline Unsur & Laboratorium & Lab AAN - PSTA & SD & RSD & $r^{2}$ & $\begin{array}{c}\text { Rasio } \\
\text { Perbedaan }\end{array}$ \\
\hline $\mathrm{Al}$ & $\begin{array}{c}\text { AAN - PSTA } \\
\text { AAN - UT }\end{array}$ & $\begin{array}{c}10,104 \pm 0,742 \% \\
9,130 \pm 0,650 \%\end{array}$ & $\begin{array}{l}1,887 \\
1,000\end{array}$ & $\begin{array}{l}18,670 \\
10,955\end{array}$ & 0,453 & 1,107 \\
\hline $\mathrm{Fe}$ & $\begin{array}{l}\text { AAN - PSTA } \\
\text { AAN - UT }\end{array}$ & $\begin{array}{l}4,919 \pm 0,082 \% \\
5,390 \pm 0,070 \%\end{array}$ & $\begin{array}{l}1,651 \\
0,272\end{array}$ & $\begin{array}{l}4,840 \\
5,052\end{array}$ & 0,721 & 0,913 \\
\hline $\mathrm{Na}$ & $\begin{array}{c}\text { AAN - PSTA } \\
\text { AAN - UT }\end{array}$ & $\begin{array}{l}2,445 \pm 0,157 \% \\
2,380 \pm 0,150 \%\end{array}$ & $\begin{array}{l}2,103 \\
0,718\end{array}$ & $\begin{array}{l}44,660 \\
30,162\end{array}$ & 0,810 & 1,027 \\
\hline K & $\begin{array}{l}\text { AAN - PSTA } \\
\text { AAN - UT }\end{array}$ & $\begin{array}{l}1,658 \pm 0,079 \% \\
1,700 \pm 0,070 \%\end{array}$ & $\begin{array}{l}0,649 \\
0,290\end{array}$ & $\begin{array}{l}2,190 \\
1,722\end{array}$ & 0,719 & 0,975 \\
\hline V & $\begin{array}{l}\text { AAN - PSTA } \\
\text { AAN - UT }\end{array}$ & $\begin{array}{l}209,839 \pm 6,955 \mu \mathrm{g} / \mathrm{g} \\
206,000 \pm 6,000 \mu \mathrm{g} / \mathrm{g}\end{array}$ & $\begin{array}{l}28,654 \\
24,061\end{array}$ & $\begin{array}{l}38,210 \\
40,806\end{array}$ & 0,583 & 1,019 \\
\hline $\mathrm{Ti}$ & $\begin{array}{l}\text { AAN - PSTA } \\
\text { AAN - UT }\end{array}$ & $\begin{array}{l}0,426 \pm 0,043 \% \\
0,439 \pm 0,032 \%\end{array}$ & $\begin{array}{l}1,581 \\
0,990\end{array}$ & $\begin{array}{l}12,080 \\
13,515\end{array}$ & 0,835 & 0,970 \\
\hline $\mathrm{Si}$ & $\begin{array}{l}\text { AAN - PSTA } \\
\text { AAN - UT }\end{array}$ & $\begin{array}{c}\text { tidak dianalisis } \\
25,500 \pm 1,000 \%\end{array}$ & 1,265 & $\begin{array}{c}- \\
4,963\end{array}$ & - & - \\
\hline $\mathrm{Mn}$ & $\begin{array}{l}\text { AAN - PSTA } \\
\text { AAN - UT }\end{array}$ & $\begin{array}{l}1379,735 \pm 61,022 \mu \mathrm{gg} / \mathrm{g} \\
1340,000 \pm 60,000 \mu \mathrm{g} / \mathrm{g}\end{array}$ & $\begin{array}{l}106,105 \\
101,182\end{array}$ & $\begin{array}{l}7,744 \\
7,568\end{array}$ & 0,724 & 1,030 \\
\hline $\mathrm{Mg}$ & $\begin{array}{l}\text { AAN - PSTA } \\
\text { AAN - UT }\end{array}$ & $\begin{array}{c}0,469 \pm 0,041 \% \\
\text { tidak dianalisis }\end{array}$ & 52,249 & 11,330 & - & - \\
\hline As & $\begin{array}{c}\text { AAN - PSTA } \\
\text { AAN - UT }\end{array}$ & $\begin{array}{l}3,382 \pm 0,197 \mu \mathrm{g} / \mathrm{g} \\
3,800 \pm 0,237 \mu \mathrm{g} / \mathrm{g}\end{array}$ & $\begin{array}{l}3,313 \\
1,472\end{array}$ & $\begin{array}{l}40,850 \\
38,734\end{array}$ & 0,878 & 0,890 \\
\hline $\mathrm{Cr}$ & $\begin{array}{l}\text { AAN - PSTA } \\
\text { AAN - UT }\end{array}$ & $\begin{array}{l}6,211 \pm 0,612 \mu \mathrm{g} / \mathrm{g} \\
5,900 \pm 0,680 \mu \mathrm{g} / \mathrm{g}\end{array}$ & $\begin{array}{l}2,042 \\
1,461\end{array}$ & $\begin{array}{l}23,810 \\
24,754\end{array}$ & 0,575 & 1,053 \\
\hline $\mathrm{Zn}$ & $\begin{array}{l}\text { AAN - PSTA } \\
\text { AAN - UT }\end{array}$ & $\begin{array}{l}271,016 \pm 9,128 \mu \mathrm{g} / \mathrm{g} \\
105,000 \pm 5,000 \mu \mathrm{g} / \mathrm{g}\end{array}$ & $\begin{array}{c}77,985 \\
6,950 \\
\end{array}$ & $\begin{array}{c}40,890 \\
6,619 \\
\end{array}$ & $-0,024$ & 2,581 \\
\hline
\end{tabular}

Untuk interpretasi yang lebih baik dari perbandingan hasil analisis dua laboratorium, dihitung nilai RSD dan rasio RSD untuk setiap elemen dan setiap laboratorium. Menurut Tabel 1, nilai RSD bervariasi antara $1,722 \%$ (K, Univ. Texas) dan 44,66 \% (Na, PSTA). Nilai RSD dan rasio RSD juga dapat digunakan untuk mengetahui homogenitas suatu sampel dan kesalahan eksperimental $[6,10,11,16]$. Oleh karena itu, untuk membandingkan hasil analisis dari kedua laboratorium tidak hanya nilai RSD saja yang diperhatikan tetapi diperhitungkan pula nilai koefisien korelasi $\left(\mathrm{r}^{2}\right)$ sehingga diketahui apakah nilai yang diberikan mempunyai beda signifikan atau tidak.

Dilihat dari nilai RSD dan nilai koefisien korelasi $\left(\mathrm{r}^{2}\right)$ dari hasil analisis dua laboratorium seperti yang tertera pada Tabel 4 diketahui bahwa unsur yang mempunyai RSD rendah dan koefisien korelasi $\left(r^{2}\right)$ tertinggi terdapat pada unsur K, Mn, Ti dan Fe. Nilai RSD rendah dan koefisien korelasi dari kedua laboratorium menunjukkan bahwa perbandingan hasil analisis kedua laboratorium tersebut sangat baik dan saling berdekatan atau tidak beda signifikan $[6,12]$.

Pada Tabel 4 dapat diketahui ada rasio perbedaan antara hasil analisis lab AAN-PSTA dengan lab AANUT. Rasio perbedaan tertinggi terdapat pada unsur Zn yaitu 2,581\%. Perbedaan ini sangat signifikan di mana hasil analisis yang diperoleh menggunakan metode relatif hampir 2 kali lipat dari metode epithermal yang dilakukan lab AAN-UT. Dilihat dari hasil pengukuran menggunakan spektrometer gamma dapat diketahui bahwa spektrum Zn terletak di antara spektrum Eu (1112 keV) dan Sc (1120 keV) [4]. Pada Gambar 2 terlihat spektrum Sc sangat dominan dibandingkan Eu dan Zn. Puncak Sc yang dominan akan mempengaruhi tailing puncak Zn. Hal ini akan mempengaruhi net area puncak Zn sekalipun sudah mengunakan software interatif peak untuk menganalisis spektrum yang overlapping sehingga berimbas pada hasil analisis kuantitatifnya.

Analisis $\mathrm{Zn}$ menggunakan metode AAN thermal dapat pula dilakukan dengan isotope $\mathrm{Zn}$ metastabil pada tenaga $436 \mathrm{keV}$ dengan waktu paruh 13,76 jam [4]. Analisis pada tenaga ini sangat baik karena tidak terinterferensi dengan tenaga lainnya. Analisis unsur $\mathrm{Zn}$ dapat juga dilakukan menggunakan isotop 68mZn. Akan tetapi untuk analisis dengan isotop ${ }^{68 m Z n}$ menggunakan reaktor Kartini daya $100 \mathrm{~kW}$ harus dilakukan pada waktu 
iradiasi tertentu guna mencapai fluen neutron teraktivasi. Hasil analisis unsur $\mathrm{Na}$ mempunyai nilai koefisien korelasi $\left(\mathrm{r}^{2}\right)$ tinggi yaitu 0,810 akan tetapi mempunyai nilai RSD yang tinggi sehingga hasil analisis dari kedua laboratorium tersebut belum dapat dikatakan terbaik berdasarkan perhitungan statistik dengan tingkat kepercayaan $95 \%$.

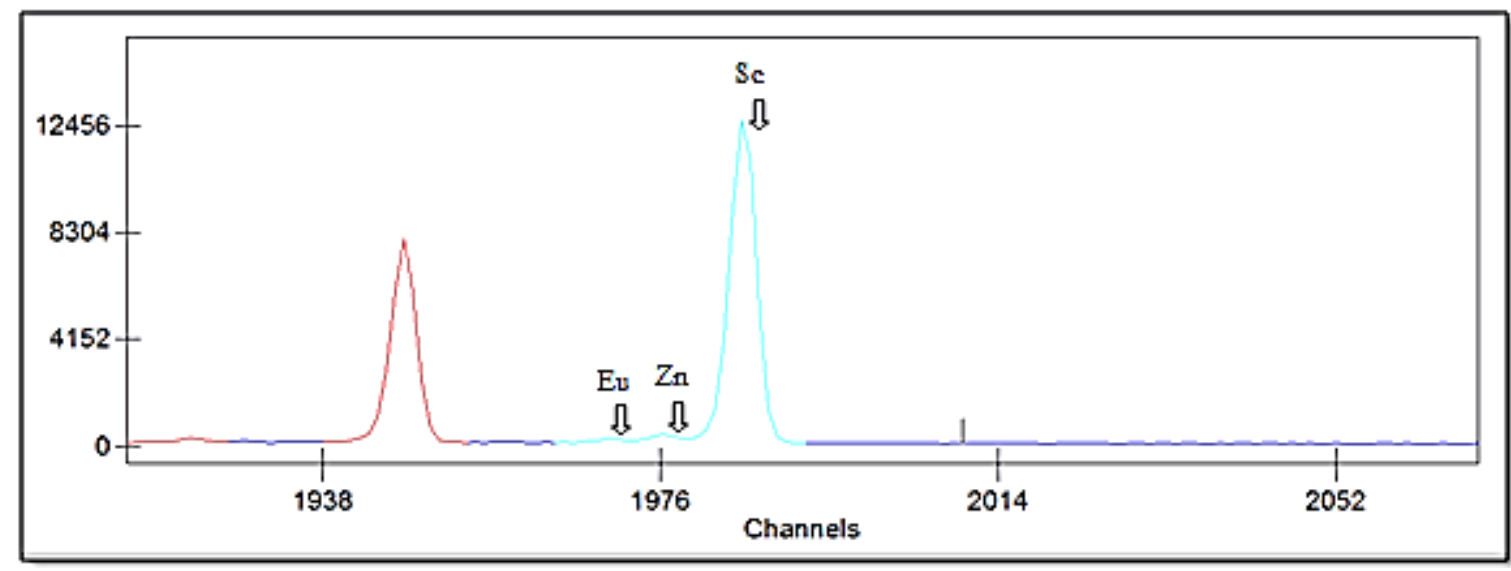

Gambar 2. Spektrum Zn hasil pengukuran sampel abu vulkanik menggunakan spektrometer gamma.

\section{KESIMPULAN}

Perbandingan hasil analisis laboratorium AAN-PSTA dan laboratorium AAN-Univ. Texas menunjukkan hasil yang memuaskan di mana dari 12 unsur target yang diminta, laboratorium AAN mampu menyajikan 11 unsur. Berdasarkan hasil perbandingan diketahui bahwa analisis unsur $\mathrm{K}, \mathrm{Mn}$, Tidan Fe dari kedua laboratorium mempunyai perbandingan yang sangat baik dan saling berdekatan, sekalipun kedua laboratorium menggunakan metode yang berbeda. Hal ini diketahui dari nilai RSD dan koefisien korelasi hasil analisis kedua laboratorium. Sedangkan dilihat dari perbedaan hasil diketahui bahwa hasil analisis unsur $\mathrm{Al}, \mathrm{Na}, \mathrm{K}, \mathrm{Fe}, \mathrm{V}, \mathrm{Mn}, \mathrm{Ti}, \mathrm{Cr}$ dan $\mathrm{As}$ dari kedua laboratorium tidak beda signifikan. Dari 11 unsur yang dilaporkan, hanya unsur $\mathrm{Zn}$ yang mempunyai nilai berbeda signifikan untuk dua laboratorium.

\section{UCAPAN TERIMA KASIH}

Penulis mengucapkan terima kasih kepada seluruh staf reaktor Kartini dan seluruh staf laboratorium AAN atas kerja sama yang baik dalam mengiradiasi, melakukan sampling dan preparasi sampel. Terima kasih juga disampaikan kepada Bonnie Canion, Camille Jacques dan Sheldon Landsberger yang telah ikut menganalisis sampel di laboratorium AAN-University of Texas USA.

\section{DAFTAR PUSTAKA}

[1] B. L. Pitblado, M. B. Cannon, H. Neff, C. M. Dehler, S. T. Nelson, "LA-ICP-MS Analysis of Quartzite from The Upper Gunnison Basin", Colorado, Journal of Archaeological Science,Vol. 40, Issue 4, 2196-2216, April (2013).

[2] I.J. Kim, J.K. Suh, K.H. Cho, J.H. Jung, Y.C. Myoung and E. Hwang., "Interlaboratroy Comparison for the Measurement of Bromine Contents In Plastic Samples Using Combustion Ion Chromatography", XX IMEKO World Congress Metrology for Green Growth September 9-14, Busan, Republic of Korea (2012).

[3] N.M. A. Mohamed, A. G. Abo El-Nor, M. Soliman, A. Ahmed,A. Aal, M. K. Shaat, "INAA laboratory results evaluation of inter-laboratory analysis test", J. Radioanal Nucl .Chem. vol. 285, 321-329 (2010). 
[4] R.R. Greenberg, P. Bode, E.A. De Nadai Fernandes, "Neutron activation analysis: A primary method of measurement", Spectrochimica Acta Part B: Atomic Spectroscopy, Vol. 66, Issues 3-4, 193-241, MarchApril (2011).

[5] B.E. Canion, Characterization of Volcanic Ash from 2010 Mt Merapi, Indonesia Eruption by Neutron Activation Analysis and Leaching Analysis, M.Sc Thesis, Presented to the Faculty of the Graduate School of The University of Texas at Austin (2012).

[6] S. Kongsria, W. Srinuttrakulb , P. Solab , A. Busamongkol, "Instrumental Neutron Activation Analysis of Selected Elements in Thai Jasmine Rice, Energy Procedia 89, 361-365 (2016).

[7] B.E. Canion, C. Jacques, S. Landsberger, A. Taftazani, "Trace Analysis of Indonesian Volcanic Ash using Thermal and Epithermal Neutron Activation Analysis", NUKLEONIKA 57(4), 585-589 (2012).

[8] M.E. Coleman, M.D. Glascock, J.D. Robertson, C. Cristache, K. Gméling, O. Culicov, M.V. Frontasyeva, M. Toma, O.G. Duliu, "An ENAA and PGAA Comparative Study of Anoxic Black Sea sediments", J. Radioanal Nucl. Chem., Vol. 279, No.1, 7-12 (2009).

[9] Y. Fiamegos, M. Vahcic, H. Emteborg, J. Snell, G. Raber, F. Cordeiro, P. Robouch, B. de la Calle, "Determination of Toxic Trace Elements in Canned Vegetables. The Importance of Sample Preparation", Trends in Analytical Chemistry 85, 57-66 (2016).

[10] R.G. Henderson, V. Verougstraete, K. Anderson, J.J. Arbildua, T.O. Brock, T. Brouwers, D. Cappellini, K. Delbeke, G. Herting, G. Hixon, I.O. Wallinder, P.H. Rodriguez, F. Van Assche, P. Wilrich, A.R. Oller, "Interlaboratory Validation of Bioaccessibility Testing for Metals", Regulatory Toxicology and Pharmacology, Vol. 70, Issue 1, October, 170-181 (2014).

[11] M. Sykes, "Proficiency Testing for The Improvement of Analytical Practice", Accred Qual Assur vol. 17, 467-471 (2012).

[12] A.L. Nichols, D.L. Aldama, M. Verpelli, Handbook Of Nuclear Data For Safeguards, IAEA, Vienna, Austria (2008).

[13] S.T. Susanti, Samin, "Uji Homogenitas dan Stabilitas Kandidat SRM Natrium Zirkonat dengan Metode XRF", Prosiding Pertemuan Dan Presentasi IImiah - Penelitian Dasar IImu Pengetahuan Dan Teknologi Nuklir, 176-183 (2012).

[14] K. Sobiech-Matura, B. Mate, T. Altzitzoglou, "Radioactivity Monitoring in Foodstuff and Drinking Water - An Overview of Performance of EU Laboratories Based on Interlaboratory Comparisons", Food Control 72, 225231 (2017).

[15] I. Baer, H. Emteborg, B. De La Calle, "Results From Two Interlaboratory Comparisons On The Measurement Of Trace Element Contents In Food Supplements - State Of The Art Of Control Laboratories In Europe", Food Chemistry 126, 1498-1504 (2011).

[16] E.E. Bockmon, A.G. Dickson, "An Inter - Laboratory Comparison Assessing The Quality of Seawater Carbon Dioxide Measurements", Marine Chemistry, Vol. 171, 20 April, 36-43 (2015). 